\title{
IMPLEMENTASI ONLINE MARKET PLACE PADA INDUSTRI RUMAHAN DI DESA MOJODANU NGUSIKAN JOMBANG
}

\author{
${ }^{1}$ Ahmad Heru Mujianto, ${ }^{2}$ Hadi Sucipto, ${ }^{3}$ Chamdan Mashuri, ${ }^{4}$ Ginanjar Setyo Permadi, \\ ${ }^{5}$ Tanhella Zein Vitadiar \\ ${ }^{1,3,5}$ Program Studi Sistem Informasi, ${ }^{4}$ Program Studi Teknik Informatika, ${ }^{2}$ Program Studi Manajemen \\ Informatika, Universitas Hasyim Asy'ari Tebuireng Jombang \\ 1ahmadmujianto@unhasy.ac.id
}

\begin{abstract}
Unemployment rate data in Indonesia according to the Central Statistics Agency shows that until 2017 there were still 7.04 million unemployed people, this is an obstacle to Indonesia's economic growth. One effort to reduce unemployment by starting your own business which of course is also equipped with skills. Building a Home Industry is not easy to have a lot of consideration and the right strategy. There are several Home Industries in Mojodanu Village Ngusikan Jombang which is engaged in culinary. Based on the analysis of the Mojodanu Village Home Industry, the low level of marketing is not only due to the limited marketing media but also because the business strategies implemented are not appropriate. So the PKM activities that will be carried out include information technology introduction training, implementation of business strategies and online marketplace based websites. The method used in PKM is by direct presentation, accompaniment, practicum and discussion so it is expected that the Home Industry players can understand and practice what has been delivered. The final result of this PKM is expected that the Mojodanu Village Home Industry players will be able to expand marketing targets that are not only conventional but can carry out online sales transactions, so as to be able to increase the productivity and income of the Mojodanu Village Home Industry and the products of the Mojodanu Village Home Industry are able to become a superior product of the typical village of Mojodanu Village, discussing Jombang.
\end{abstract}

Keywords: Home Industry, Marketplace, PKM, Online

\begin{abstract}
Abstrak
Data tingkat pengangguran di Indonesia menurut Badan Pusat Statistik menunjukkan bahwa hingga tahun 2017 masih terdapat 7,04 juta orang belum bekerja, hal tersebut menjadi penghambat pertumbuhan ekonomi Indonesia. Salah satu upaya mengurangi pengangguran dengan memulai bisnis sendiri yang tentunya juga dibekali dengan ketrampilan. Membangun Industri Rumahan tidaklah mudah harus banyak pertimbangan dan strategi yang tepat. Terdapat beberapa Industri Rumahan di Desa Mojodanu Ngusikan Jombang yang bergerak dibidang kuliner. Berdasarkan hasil analisa pada Industri Rumahan Desa Mojodanu, rendahnya tingkat pemasaran tidak hanya disebabkan karena media pemasaran yang terbatas tetapi juga karena strategi bisnis yang diterapkan kurang tepat. Sehingga kegiatan PKM yang akan dilaksanakan meliputi pelatihan pengenalan teknologi informasi, implementasi strategi bisnis dan implementasi website marketplace berbasis online. Metode yang digunakan dalam PKM ini dengan cara langsung presentasi, pendampingan, praktikum dan berdiskusi sehingga diharapkan pelaku Industri Rumahan dapat memahami dan mempraktikkan apa yang telah disampaikan. Hasil akhir PKM ini diharapkan pelaku Industri Rumahan Desa Mojodanu mampu memperluas target pemasaran yang tidak hanya secara konvensional tetapi sudah bisa melakukan transaksi penjualan secara online sehingga mampu meningkatkan produktivitas dan pendapatan Industri Rumahan Desa Mojodanu dan produk dari Industri Rumahan Desa Mojodanu mampu menjadi produk unggulan daerah khas desa Mojodanu Ngusikan Jombang.
\end{abstract}

Kata Kunci : Industri Rumahan, Marketplace, PKM, Online

\section{PENDAHULUAN}

Indonesia merupakan salah satu negara besar di Asia bahkan dunia, sehingga salah satu permasalahan yang sering dihadapi adalah tingkat pengangguran yang setiap tahun mengalami peningkatan. Seperti data yang dirilis oleh Badan Pusat Statistik (BPS) bahwa, pengangguran di Indonesia di tahun 2017 mengalami kenaikan jumlah sebesar 10.000 orang, sehingga menjadi 7,04 juta orang pada Agustus 2017. Jumlah tersebut lebih banyak dibandingkan pada Agustus 2016 sebesar 7,03 
juta orang. Kepala BPS Kecuk Suhariyanto mengatakan, meningkatnya jumlah angakatan kerja di Indonesia, tetapi tidak tersedianya lapangan kerja yang mampu menampung tenaga kerja, menjadikan angka pengangguran semakin meningkat (Julianto, 2017).

Upaya yang dapat dilakukan untuk meminimalkan angka pengangguran diantaranya adalah dengan memulai mencoba membuka usaha sendiri atau mendirikan usaha mikro, kecil, dan menengah tentunya dengan ketrampilan yang sudah dimiliki. Seperti data yang dirilis oleh Kementrian Perinsdustrian (Kemenperin) tahun 2017, bahwa pada periode lima tahun terakhir, kontribusi sektor Industri Rumahan terhadap produk domestik bruto mengalami kenaikan dari 57,84 persen naik menjadi 60,34. Pada periode yang sama juga terjadi peningkatan serapan tenaga kerja dari 96,99 persen menjadi 97,22 persen. Sehingga hal tersebut menjadi peluang bagi pemerintah Indonesia untuk memajukan perekonomian dan mengurangi angka pengangguran.

Terdapat beberapa Industri Rumahan di desa Mojodanu Kecamatan Ngusikan Kabupaten Jombang yang bergerak dibidang kuliner yaitu kripik talas, kripik pisang dan stik labu, sehingga Industri Rumahan di desa Mojodanu mengangkat dan melestarikan produk olahan pertanian dan bisa menjadi produk unggulan desa Mojodanu. Industri Rumahan tersebut berada dalam pembinaan Kader PKK desa Mojodanu, karena hal tersebut merupakan salah satu kegiatan rutin kader PKK dalam mengembangkan keterampilan mereka. Selama ini Industri Rumahan tersebut hanya melakukan pemasaran secara konvensional dan hanya melayani pesanan dari warga sekitar belum bisa menjangkau pemasaran yang lebih luas. Salah satu upaya yang dapat dilakukan untuk meningkatkan pemasaran adalah dengan memanfaatkan penjualan secara online melalui penerapan ke dalam website marketplace.
Menurut Kementerian Koperasi dan Usaha Kecil Menengah (Kemenkop UKM) tahun 2017, sebanyak 3,79 juta Industri Rumahan sudah menggunakan platform online pada pemasaran produknya. Jumlah ini berkisar 8 persen dari total pelaku Industri Rumahan yang ada di Indonesia, yakni 59,2 juta. Berdasarkan hal tersebut maka Industri Rumahan di desa Mojodanu juga perlu memulai pemasaran secara online. Apalagi menurut hasil survei yang dilakukan oleh Asosiasi Penyelenggara Jasa Internet Indonesia (APJII), tingkat pengguna internet di Indonesia pada tahun 2017 mencapai 143,26 juta jiwa. Angka tersebut mengalami peningkatan dibandingkan pada tahun sebelumnya yang terpantau mencapai 132,7 juta jiwa. Sehingga hal tersebut menjadi peluang untuk memperluas pemasaran dengan memanfaatkan platform online ataupun sosial media (Setiawan, 2018).

Selain melakukan pemasaran secara online, Industri Rumahan di Desa Mojodanu juga perlu menganalisa dari segi strategi bisnisnya seperti dalam hal promosi, karena dengan menggunakan teknik dan metode promosi yang tepat, akan mampu memperkenalkan produk kepada masyarakat secara luas dan meningkatkan penjualan produk. Berdasarkan permasalahanpermasalahan tersebut, kegiatan pengabdian kepada masyarakat ini bertujuan untuk memberikan pemahaman kepada pelaku Industri Rumahan di desa Mojodanu supaya menerapkan teknologi dalam proses bisnisnya dengan didukung sebuah website marketplace berbasis online yang akan membantu sebagai wadah untuk memperkenalkan produk serta menerapkan strategi promosi yang tepat untuk memperluas pemasaran produk, sehingga hasil dari kegiatan ini diharapkan mampu meningkatkan produktifitas dan pemasukkan bagi Industri Rumahan tersebut. 


\section{DASAR TEORI}

\section{Industri Rumahan}

Industri rumahan masuk dalam kategori UMKM (Usaha Mikro Kecil Mengengah) yang merupakan usaha produktif yang dimiliki

mendukung pendapatan rumah tangga. Keberadaan IR diharapkan mampu memacu perekonomian di tengah perlambatan ekonomi yang terjadi saat ini. Pemanfaatan konsep pemasaran berbasis teknologi digital memberikan harapan bagi IR untuk berkembang menjadi pusat kekuatan ekonomi (Purwana, dkk. 2017).

\section{Online Market Place}

Istilah Online Market Place mengarah pada pemanfaatan teknologi digital dalam berbisnis (Digital Marketing).Digital marketing didefinisikan juga sebagai kegiatan pemasaran yang menggunakan media berbasis internet (Wardhana, 2015). Internet adalah alat yang cukup berpengaruh untuk bisnis. Roger dalam Purwana (2017) mengungkapkan ciri-ciri internet adalah sebagai berikut:

1) Interactivity, kemampuan perang-kat teknologi memfasilitasi komu-nikasi antar individu seperti bertatap muka langsung. Komuni-kasi terjalin sangat interaktif sehingga para partisipan bisa berkomunikasi dengan lebih akurat, efektif, dan memuaskan.

2) Demassification, pesan dapat dipertukarkan kepada partisipan yang terlibat dalam jumlah besar.

3) Asynchronous, teknologi komuni-kasi mempunyai kemampuan untuk mengirimkan dan menerima pesan pada waktu yang dikehen-daki setiap peserta.

\section{METODE}

Metode yang digunakan dalam melaksanaan PKM ini adalah dengan pendekatan secara langsung dengan pelaku perorangan maupun badan usaha yang telah memenuhi kriteria sebagai usaha mikro. Industri Rumahan (IR) memiliki peran penting dalam laju ekonomi Indonesia terutama dalam penciptaan lapangan kerja dan pemberdayaan rumah tangga yang Industri Rumahan di desa Mojodanu, adapun tahapan-tahapan yang dilakukan dapat dilihat pada Gambar 1.

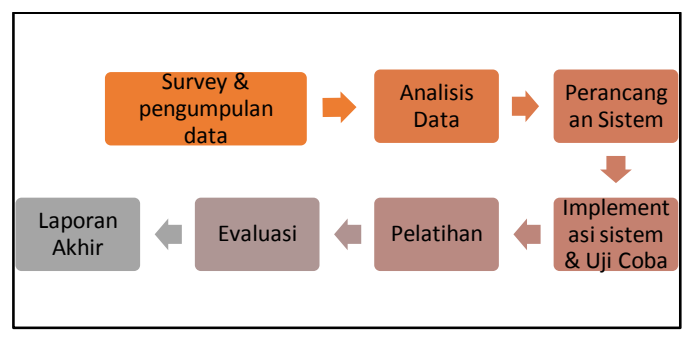

Gambar 1. Roadmap Pelaksanaan PKM

Berikut ini penjelasan untuk tiap tahapan :

\section{Survey dan Pengumpulan Data}

Tahapan pertama adalah melaksanakan survey ke lokasi Industri Rumahan di desa Mojodanu untuk melihat secara langsung proses bisnis yang dijalankan selama ini disana dan melakukan wawancara dengan pelaku Industri Rumahan di desa Mojodanu. Hasil dari survey dan wawancara berupa pengumpulan data yang akan berguna untuk menindaklanjuti proses selanjutnya. Survey dilakukan pada saat pelaksanaan KKNT di desa Mojodanu, yakni pada bulan Agustus 2019, dengan langsung mendatangi tempat produksi Industri Rumahan dan melakukan pengamatan serta wawancara dengan pelaku Industri Rumahan di desa Mojodanu.

Berdasarkan hasil survey dan pengumpulan data, didapatkan informasi bahwa di desa Mojodanu terdapat beberapa industri rumahan, tetapi kebanyakan industri rumahan tersebut tidak mampu berkembang lebih luas, bahkan ada yang hanya bertahan sebentar dan gulung tikar. Menurut pengakuan para pelaku, kurang berkembangnya industri rumahan disana, karena desa Mojodanu termasuk desa yang cukup jauh dari 
kota/kabupaten Jombang dan jauh dari akses

tidak banyak yang mengetahui produk mereka, perlu adanya inovasi dalam memperkenalkan produk mereka sehingga pemasaran semakin meluas tanpa terhalang jarak yang jauh.

\section{Analisis Data}

Tahapan kedua adalah analisis data, yang sebelumnya telah dilakukan proses pengumpulan pada lokasi pengabdian. Data yang sudah terkumpul dilakukan proses analisis data untuk mengetahui fokus permasalahan yang dihadapi oleh masyarakat, dan mencari alternative solusi atas permasalahan tersebut. Solusi yang didapatkan nantinya akan diimplementasi kepada masyarakat untuk mengetahui apakah solusi yang ditawarkan mampu diserap oleh masyarakat atau tidak, jika dirasa solusi kurang tepat selanjutnya dapat dikembangkan solusi yang lain untuk pengembangan program kedepannya.

Berdasarkan hasil analisis data, didapatkan solusi yakni perlu adanya sebuah sistem yang mampu mengolah produk industri rumahan di desa Mojodanu serta mempromosikan produk mereka.

\section{Perancangan Sistem}

Berdasarkan solusi yang didapatkan, selanjutnya solusi tersebut dirubah ke dalam perancangan sistem, karena bidang fokus pada pengabdian ini adalah pemanfaatan teknologi untuk masyarakat. Sehingga solusi yang ditawarkan berupa sistem informasi untuk pengolahan hasil produksi masyarakat desa Mojodanu serta mempromosikan produk mereka melalui sistem tersebut. Tahap perancangan ini akan mulai didesain sistem yang diusulkan, mulai dari perancangan basisdata hingga proses perancangan sistem. Sistem yang akan dibangun berbasis website, sehingga pengguna dapat mengakses sistem tersebut dimanapun dan kapanpun selama terhubung dengan internet. Pada sistem ini keramaian,

sehingga

dapat diakses oleh 3 pengguna, yaitu pengunjung, pembeli/ penjual, dan admin.

\section{Implementasi dan Uji Coba Sistem}

Tahap ini merupakan tindak lanjut dari tahap sebelumnya, yakni sistem yang sudah selesai dikerjakan selanjutnya dilakukan uji coba implementasi sistem. Proses implementasi dan pengujian ini bertujuan agar sistem yang dibangun tidak mengalami permasalahan, dan jika ada permasalahan pada sistem akan segera diperbaiki sebelum sistem ini benar-benar diterapkan pada masyarakat.

\section{Pelatihan}

Sistem yang sudah berhasil dibuat selanjutnya akan diterapkan pada masyarakat dengan cara memberikan pelatihan tentang penggunaan sistem tersebut. Pelatihan ini tidak hanya seputar penggunaan sistem tetapi juga berkaitan dengan strategi pemasaran yang baik untuk mengolah proses bisnis. Pada pelatihan sistem ini meliputi pembuatan akun sebagai penjual, cara memasukkan data produk, cara mempromosikan produk, cara menangani ketika ada pesanan, cara pengiriman produk dan cara melakukan transaksi pembayaran.

\section{Evaluasi}

Tahap selanjutnya adalah evaluasi, yaitu untuk mengetahui sejauh mana pemahaman pelaku Industri Rumahan terhadap materi maupun pelatihan yang sudah didapatkan. Kriteria keberhasilan dalam PKM ini adalah jika $80 \%$ peserta mampu mengetahui pentingnya pemanfaatan teknologi informasi dalam menjalankan proses bisnis dan mampu menjalankan/mengoperasikan website online marketplace dengan baik.

\section{Laporan Akhir}

Tahapan terakhir pada pengabdian masyarakat adalah membuat laporan akhir dari hasil pelaksanaan pengabdian. Laporan akhir ini sebagai salah satu tanggungjawab pengabdi kepada lembaga karena telah dibiayai dalam 
melaksanakan pengabdian kepada masyarakat. berisi uraian hasil pengabdian masyarakat mulai dari tahapan awal hingga tahap akhir dan juga berisi laporan penggunaan dana atas pengabdian yang telah dilakukan.

\section{HASIL DAN PEMBAHASAN}

Pengabdian kepada masyarakat ini merupakan tindak lanjut dari kegiatan KKNT yang dilaksanakan pada bulan Juli-Agustus 2019. Berdasarkan hasil pengamatan dan observasi yang dilaksanakan pada saat KKNT, diketahui bahwa pada desa Mojodanu terdapat beberapa masyarakat yang bekerja dalam produksi produk industri rumahan, hal tersebut yang menjadikan topik pada pengabdian ini berfokus dalam pembuatan online marketplace dan pengenalan teknologi informasi pada usaha/bisnis industri rumahan. Berikut ini hasil yang didapatkan dari hasil pelaksanaan PKM ini:

\section{Website Online Marketplace}

Salah satu produk dari hasil pelaksanaan PKM ini berupa sistem/website online marketplace yang dipergunakan sebagai media bagi para pelaku bisnis industri rumahan dalam memasarkan produk mereka. Website ini dijalankan oleh tiga aktor yakni administrator, pelapak, dan pembeli (pengunjung). Berikut ini tampilan dan fitur-fitur yang terdapat dalam website online marketplace.

\section{1) Tampilan Halaman Utama}

Halaman ini merupakan halaman awal ketika kita membuka atau mengakses website online marketplace. Halaman ini dapat diakses oleh siapapun selama pengguna memasukkan alamat website dengan benar dan tersambung dengan jaringan internet. Pada halaman ini terdapat beberapa fitur seperti kotak pencarian, tombol login bagi pelapak, tombol pendaftaran bagi pengguna yang mau menjadi pelapak, tampilan kategori produk, tampilan produkproduk yang dijual oleh berbagai pelapak dengan disertai keterangan harga. Berikut ini
Laporan

akhir

ini

tampilan halaman utama seperti yang terlihat pada Gambar 2.

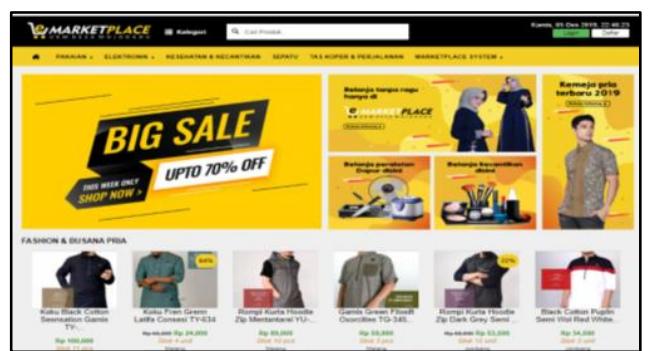

Gambar 2. Halaman Utama Marketplace

\section{2) Tampilan Halaman Daftar Produk}

Halaman ini memuat data produk apa saja yang telah diposting oleh setiap pelapak, jadi para pembeli atau pengunjung dapat melihat produk-produk yang dijual oleh pelapak. Selain ini pengunjung atau pembeli juga dapat memanfaatkan fitur pencarian untuk menemukan produk yang mereka cari secara lebih cepat. Berikut ini tampilannya seperti yang terlihat pada Gambar 3.

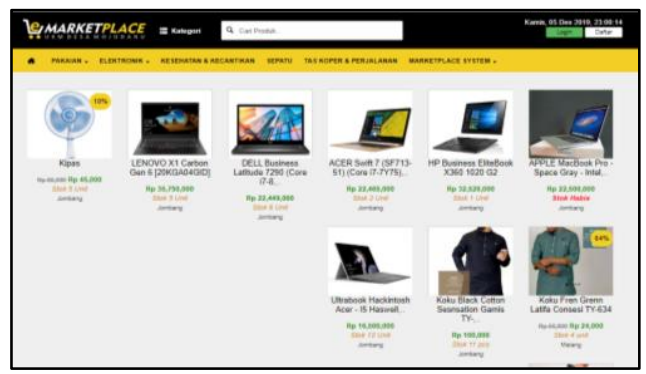

Gambar 3. Halaman Daftar Produk

\section{3) Tampilan Halaman Detail Produk}

Halaman ini merupakan hasil dari produk yang diklik (dipilih) oleh pengguna. Jadi pada saat berada pada halaman awal, kemudian pengguna memilih salah satu produk, maka pengguna akan dibawa ke dalam halaman produk. Pada halaman ini terdapat detail/keterangan dari produk yang kita pilih secara jelas dan terperinci, jadi pembeli sebelum memutuskan untuk membeli produk dapat mengamati detail gambar produk dan detail keterangan produk. Berikut tampilannya seperti yang terlihat pada Gambar 4. 


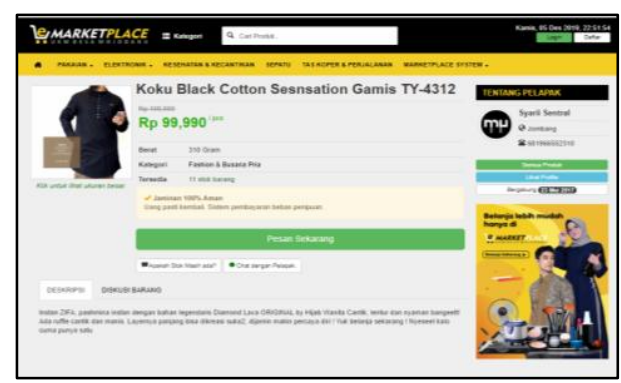

Gambar 4. Halaman Detail Produk

4) Tampilan Halaman Pendaftaran Pelapak Ketika seorang pelapak ingin memasarkan produk mereka ke dalam website online marketplace, terlebih dahulu mereka harus mendaftarkan diri dengan cara menekan tombol "Daftar" yang terdapat pada menu bagian atas. Selanjutnya pelapak akan dibawa ke halaman pendaftaran pelapak, pada halaman ini pelapak diminta untuk mengisi identitasnya sesuai dengan format isian yang sudah tersedia. Berikut ini tampilan halaman pendaftaran pelapak seperti yang terlihat pada Gambar 5.

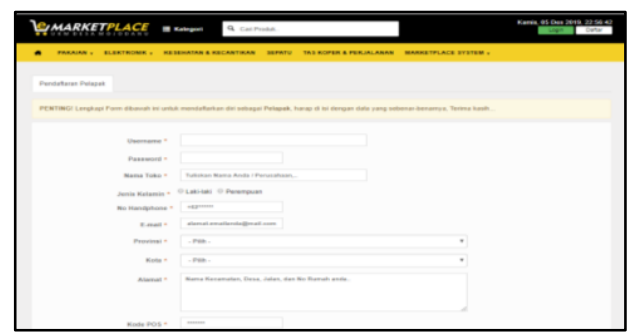

Gambar 5.Halaman Pendaftaran Pelapak

\section{5) Tampilan Halaman Daftar Pelapak}

Halaman ini berisikan data pelapak yang sudah mendaftar ke dalam website online marketplace. Berikut ini tampilannya seperti yang terlihat pada Gambar 6 .

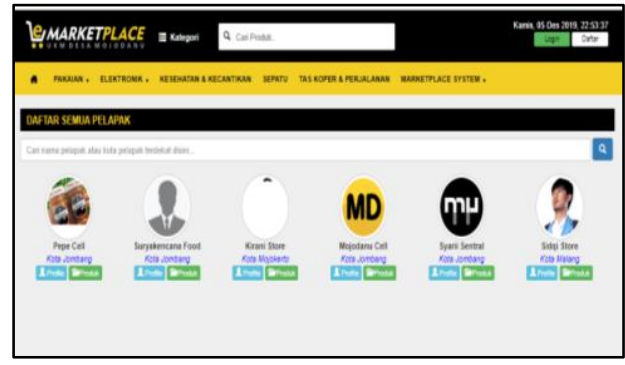

Gambar 6. Halaman Data Pelapak

\section{6) Tampilan Halaman Cara Pemasanan}

Halaman ini berisi informasi ketika pembeli atau pengunjung ingin melakukan pembeli terhadap produk yang mereka inginkan. Berikut ini tampilan halaman cara pemesanan yang terlihat pada Gambar 7.

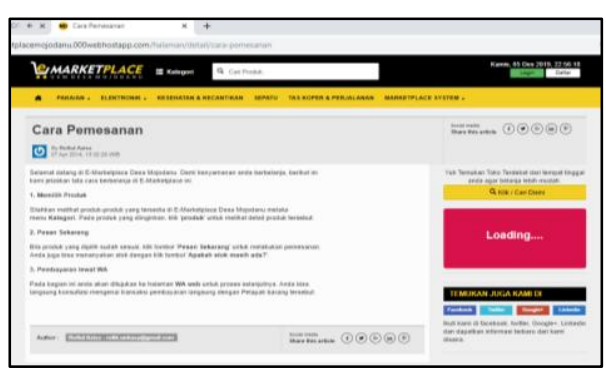

Gambar 7. Halaman Cara Pemasanan

\section{7) Tampilan Halaman Login Pelapak}

Halaman ini digunakan oleh pelapak untuk masuk ke dalam halaman pelapaknya, dengan catatan pelapak tersebut sebelumnya telah melakukan pendaftaran akun pelapak. Untuk masuk pelapak diminta memasukkan username dan password selanjutnya menekan tombol Sign In. Berikut ini tampilannya seperti yang terlihat pada Gambar 8.

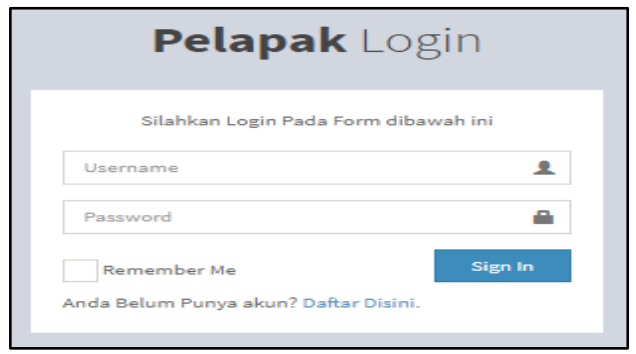

Gambar 8. Halaman Login Pelapak

\section{8) Tampilan Halaman Utama Pelapak}

Halaman ini merupakan halaman utama pelapak setelah berhasil masuk ke dalam sistem. Halaman ini berisi informasi data pelapak dan beberapa fitur untuk pengaturan produk pelapak. Berikut ini tampilannya seperti yang terlihat pada Gambar 9. 


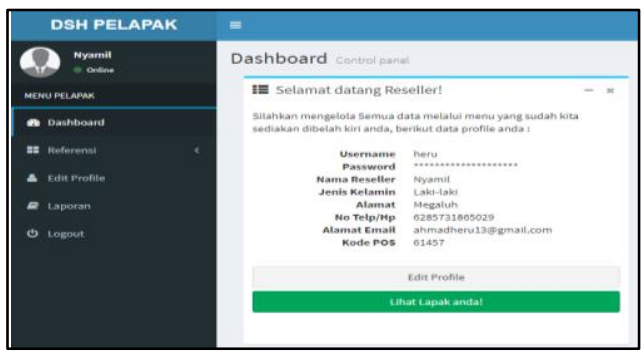

Gambar 9. Halaman Utama Pelapak

\section{9) Tampilan Halaman Tambah Data Produk}

Pelapak dapat menambahkan produk yang akan mereka jual dengan memilih menu tambah data produk dan mengisi form isian produk sesuai dengan kriteria produk dan selanjutnya produk akan muncul pada halaman utama website online marketplace.

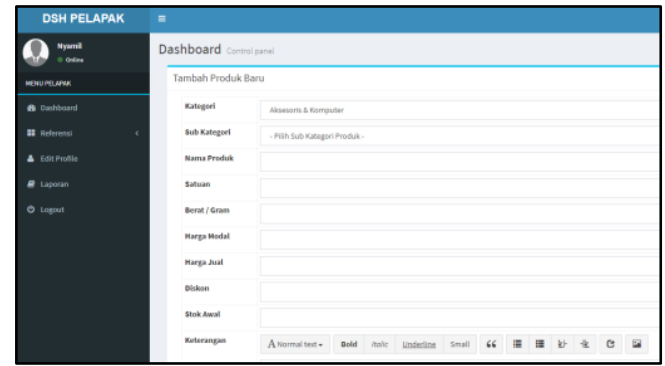

Gambar 10. Halaman Tambah Produk Pelapak

\section{0) Tampilan Halaman Edit Profil}

Halaman ini digunakan oleh pelapak untuk merubah identitas pelapak, seperti password, nama pelapak, alamat pelapak dan sebagainya. Berikut ini tampilannya seperti yang terlihat pada Gambar 11.

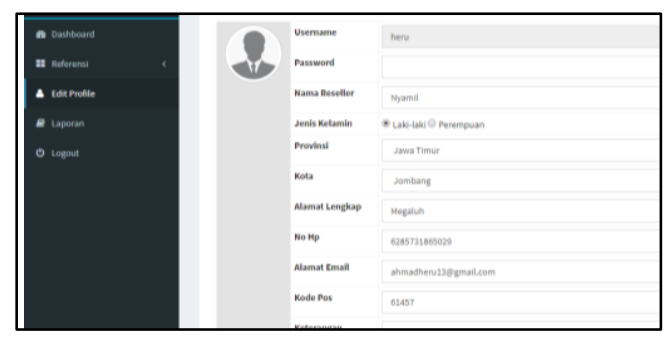

Gambar 11. Halaman Profil Pelapak

\section{1) Tampilan Halaman Login Admin}

Halaman login admin ini digunakan oleh administrator untuk masuk ke dalam sistem adminnya. Untuk masuk ke dalam sistem, admin diminta untuk memasukkan username, password dan kode keamanan untuk memberikan antisipasi terhadap keamanan sistem. Berikut ini tampilannya seperti yang terlihat pada Gambar 12.

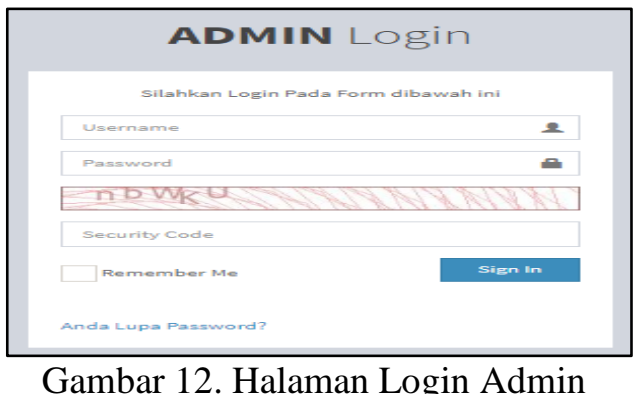

12) Tampilan Halaman Utama Admin

Halaman ini merupakan halaman utama bagi admin setelah berhasil login ke dalam sistem. Pada halaman ini terdapat beberapa pengaturan yang bisa dilakukan admin untuk mengelola sistem. Seperti pengaturan website, pelapak, profil, produk, kategori produk, dan sebagainya. Berikut ini tampilan halaman utama admin seperti yang telihat pada Gambar 13.

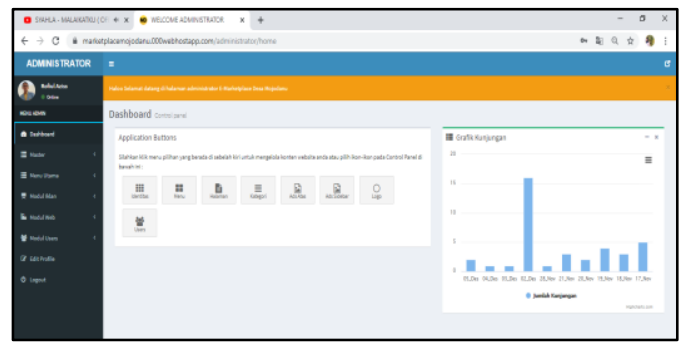

Gambar 13. Halaman Utama Administrator

\section{3) Tampilan Halaman Data Pelapak}

Halaman ini berisi informasi pelapak yang sudah terdaftar ke dalam website online marketplace. Berikut ini halaman data pelapak seperti yang terlihat pada Gambar 14 .

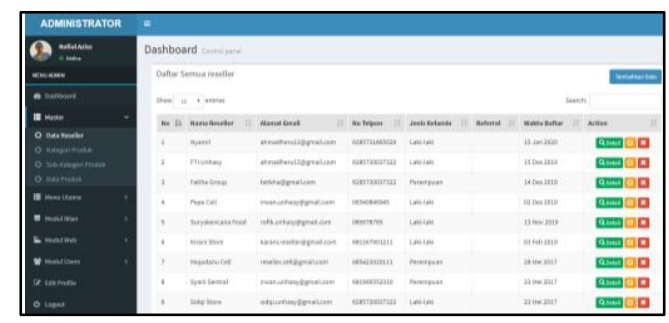

Gambar 14. Halaman Data Pelapak Administrator 


\section{4) Tampilan Halaman Kategori Produk}

Halaman ini merupakan halaman untuk mengelola kategori produk yang akan digunakan pelapak untuk menambahkan produk mereka ke dalam kategori produk. Admin dapat menambah, merubah dan menghapus data kategori produk. Berikut ini tampilannya seperti yang terlihat pada Gambar 15.

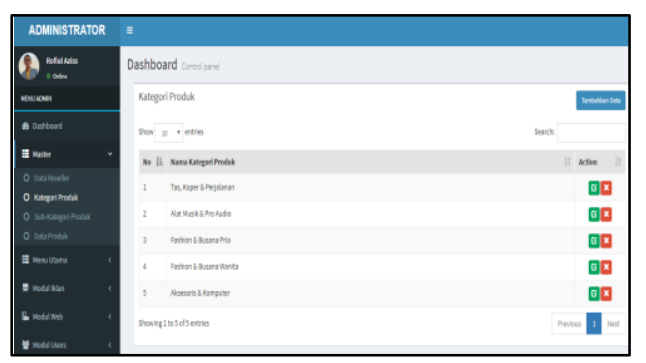

Gambar 15. Halaman Kategori Produk Administrator

\section{5) Tampilan Halaman Sub Kategori Produk}

Halaman ini digunakan oleh admin untuk mengelola data sub kategori produk, yang meliputi menambah, merubah dan menghapus data sub kategori produk. Berikut ini tampilannya seperti yang terlihat pada Gambar 16.

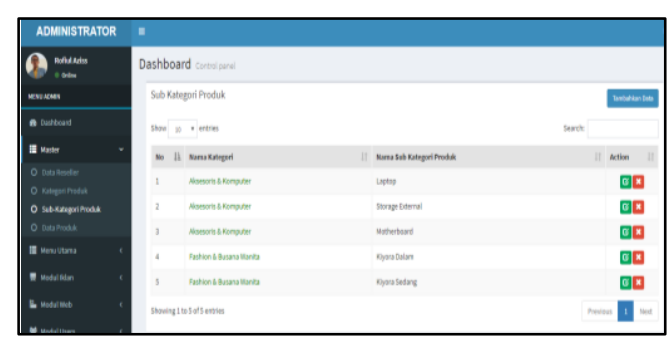

Gambar 16. Halaman Sub Kategori Produk

Administrator

\section{6) Tampilan Halaman Data Produk}

Halaman ini memuat informasi data semua produk yang telah diposting oleh pelapak. Admin dapat memantau data produk tersebut. berikut ini tampilan halaman data produk pada halaman administrator seperti yang terlihat pada Gambar 17.

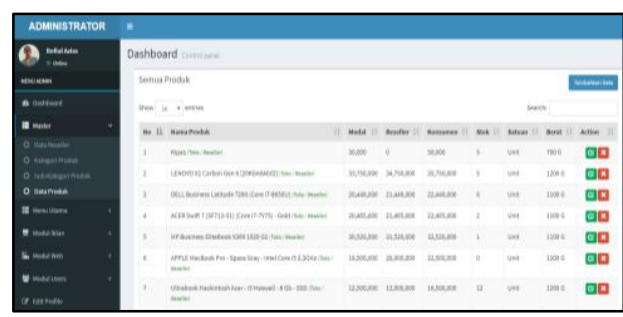

Gambar 17. Halaman Data Produk

Administrator

\section{7) Tampilan Halaman Edit Profil Admin}

Halaman ini merupakan halaman yang digunakan oleh admin untuk melakukan perubahan data profil admin, yang meliputi password, nama, nomor telp dan foto. Berikut ini tampilan dari halaman edit profil admin seperti yang terlihat pada Gambar 18 .

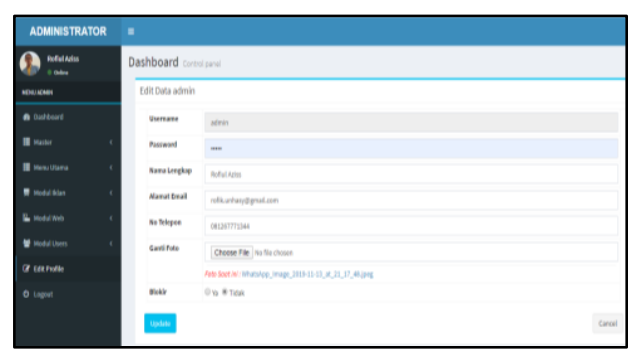

Gambar 18. Halaman Edit Profil Administrator

\section{Hasil Pelaksanaan Pelatihan}

Setelah dilaksanakan pelatihan pada tanggal 26 Desember 2019, hasil yang diperoleh dari pelatihan tersebut adalah :

1) Sebanyak 12 peserta memahami dan sepakat akan pentingnya penggunaan teknologi informasi dalam kehidupan, terutama dalam mendukung kegiatan bisnis seperti untuk pemasaran secara online.

2) Peserta pelatihan dapat mengikuti dengan baik setiap materi yang disampaikan oleh pemateri.

3) Setiap peserta pelatihan dapat mempraktekkan setiap instruksi yang diberikan oleh pemateri yang berkaitan dengan cara penggunaan website online marketplace.

4) Tidak semua peserta memiliki laptop sehingga untuk penggunaan website 
online marketplace sebagian

mengaksesnya menggunakan smartphone.

Berikut ini dokumentasi foto hasil pelaksanaan pelatihan PKM yang telah dilaksanakan pada tanggal 26 Desember 2019, dan dilaksanakan pada salah satu rumah warga desa Mojodanu, dengan jumlah peserta 12 orang.

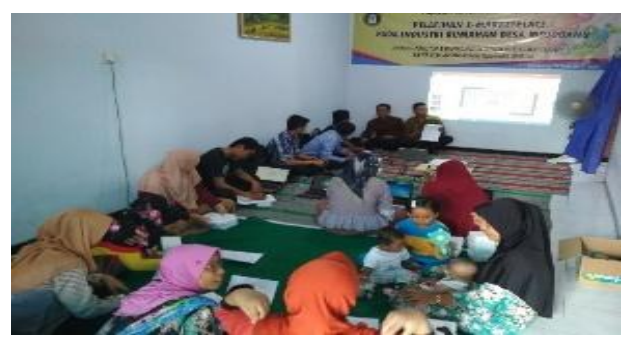

Gambar 19. Foto Pelaksanaan PKM 1

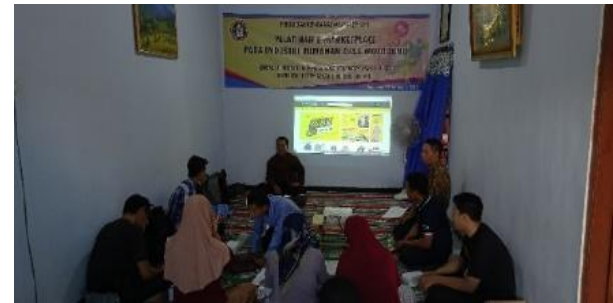

Gambar 20. Foto Pelaksanaan PKM 2

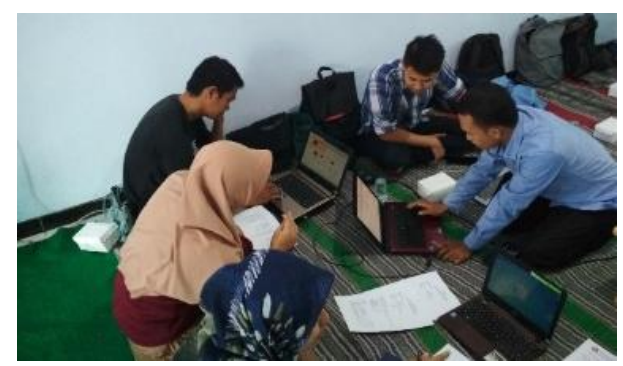

Gambar 21. Foto Pelaksanaan PKM 3

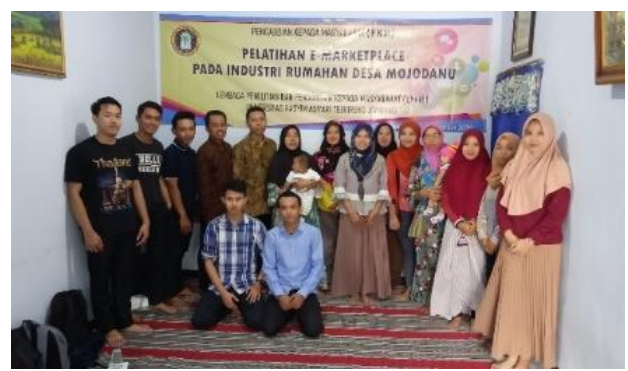

Gambar 22. Foto Pelaksanaan PKM 4

\section{Analisa Terhadap Hasil yang diperoleh}

Berdasarkan hasil yang didapatkan pada saat pelatihan, diketahui bahwa semua peserta antusias dalam menyimak dan mempraktekkan setiap materi yang disampaikan, hal tersebut terbukti dengan adanya pertanyaan dari peserta. Selain itu para peserta juga sangat ramah dan menerima kedatangan tim pelaksana PKM, sehingga tim dapat dengan mudah menyampaikan materi kepada peserta. Diharapkan dengan adanya pelatihan ini akan memberikan wawasan dan pengetahun kepada para peserta tentang peranan teknologi informasi dan para peserta mampu mengembangkan usahanya lebih luas dan lebih produktif.

\section{Evaluasi Kegiatan}

Kegiatan pelatihan ini dikatakan berhasil jika mayoritas peserta memahami setiap materi yang disampaikan oleh tim pelaksana PKM. Untuk itu pada akhir pelatihan peserta diminta mengisi kuesioner pemahaman peserta terhadap materi. Berikut ini hasil rekapitulasi kuesoiner peserta.

1) Pemahaman Peserta Terhadap Materi

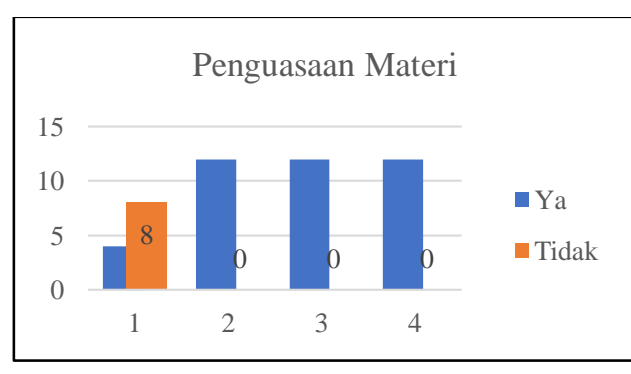

Gambar 23. Grafik Pemahaman Materi

Berdasarkan data pada Gambar 23, dapat disimpulkan bahwa semua peserta dapat memahami dan mengerti terkait materi yang disampaikan dan dapat memberikan nilai manfaat bagi para peserta, sehingga pemberian materi yang disampaikan pemateri dapat dikatakan berhasil. 
2) Penggunaan dan Pemanfaatan Sistem EMarketplace

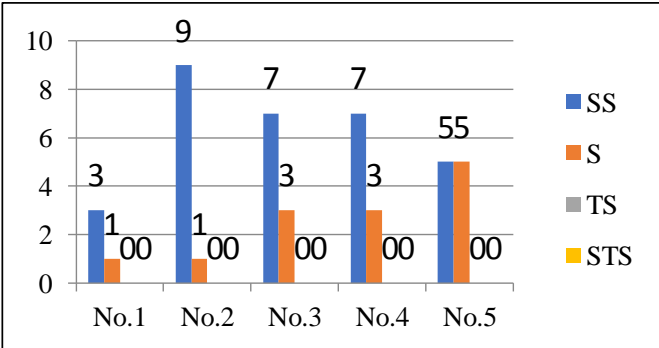

Gambar 24. Grafik Panggunaan dan Pemanfaatan Sistem E-Marketplace

Berdasarkan data pada Gambar 24 diatas, dapat disimpulkan bahwa semua peserta dapat memahami dan menggunakan sistem EMarketplace, sehingga setuju dengan adanya penggunaan teknologi informasi dalam membantu pekerjaan dan pengembangan bisnis industri rumahan.

\section{SIMPULAN}

PKM ini berfokus dalam pemanfaatan teknologi informasi untuk diterapkan pada pelaku industri rumahan, khususnya pada masyarakat desa Mojodanu. Bentuk implementasinya adalah dengan membuat sistem berbasis website, yang mampu mengelola data-data produksi industri rumahan secara lebih teratur dan mampu mempromosikan produk mereka pada website tersebut, dengan cara memajang produk mereka pada website. Adapun website tersebut kami namankan E-Marketplace Mojodanu.

Implementasi dari sistem ini kepada masyarakat desa Mojodanu telah dilaksanakan pada tanggal 26 Desember 2019, dengan cara dilaksanakan pelatihan pemanfaatan teknologi menggunakan website E-Marketplace Mojodanu. Peserta yang hadir sebanyak 12 peserta yang terdiri dari masyarakat yang memiliki usaha rumahan / bisnis rumahan.
Hasil pelaksanaan pelatihan dievaluasi dengan pengisian kuesioner oleh para peserta yang menunjukkan bahwa semua peserta dapat memahami semua materi yang disampaikan saat pelatihan dan semua peserta setuju dengan adanya penggunaan teknologi informasi dalam membantu proses bisnis mereka, khususnya dalam pemasaran produk industri rumahan.

\section{DAFTAR PUSTAKA}

Badan Pusat Statistik. 2017. https://www.bps.go.id/. (diakses 28 Nopember 2019).

Fitri, D. A., \& Mansur, M. (2018). Pelatihan Desain dan Promosi Online Produk Kerupuk Ikan dan Kerupuk Sagu di Kuala Alam Kecamatan Bengkalis. Batoboh, 3(1), 48-54.

Julianto. 2017. Jumlah Pengangguran Naik. https://ekonomi.kompas. com/ (diakses 28 Nopember 2019).

Kemenkop. 2017. http://www.depkop.go. id/ (diakses 28 Nopember 2019).

Kemenperin. 2017. http://www.kemen perin.go.id/artikel/14200/Kontribusi-

UMKM-Naik (diakses 28 Nopember 2019).

Purwana, D., Rahmi, R., \& Aditya, S. (2017). Pemanfaatan Digital Marketing Bagi Usaha Mikro, Kecil, Dan Menengah (UMKM) Di Kelurahan Malaka Sari, Duren Sawit. Jurnal Pemberdayaan Masyarakat Madani (JPMM), 1(1), 1-17.

Setiawan. 2018. Kenaikan Pengguna Internet di Indonesia Tahun 2017. https://ekonomi.kompas.com/ (diakses 28 Nopember 2019)

Suharto, M., Ardhianto, D. T., Ismail, A. I., \& Prameswari, N. S. (2017). Pelatihan Pengelolaan Website Toko Online Bagi UMKM di Kawasan Pasar Tradisional Klewer Surakarta Sebagai Strategi 
Menghadapi Masyarakat Ekonomi Asean (MEA). Desain Komunikasi Visual, Manajemen Desain dan Periklanan (Demandia), 229-245.

Ujiandari, R., \& Saputro, A. (2018, December). Pelatihan Penerapan ECommerce Menggunakan Tokopedia Untuk Usaha Mikro, Kecil Menengah (UMKM) Kota Tangerang. In Seminar Nasional Pengabdian Kepada Masyarakat (PKM) (Vol. 1, No. 1, pp. 811-818).

Wardhana, A. (2015). Strategi Digital Marketing dan Implikasinya pada Keunggulan Bersaing UKM di Indonesia. 